\title{
AKAP2 Gene
}

National Cancer Institute

\section{Source}

National Cancer Institute. AKAP2 Gene. NCI Thesaurus. Code C158484.

This gene is involved in the regulation of protein kinase A activity. 